\title{
The paradoxical image of the west in different ideologies and essentialism in Turkish politics ${ }^{1}$
}

\section{Introduction}

In recalling the research in Ismet Parlak and Özlem Kiliçarslan's interesting article "The west or the EU as "the other" from the perspective of national pride'2 this article aims to explore why the EU (or the west) has a role in the Turkish public sphere and its reflections in the different ideologies in Turkey. In this sense, the first section explains Turkish nationalism and its paradoxical mindset, while the second evaluates how and why this mindset is reflected in the different ideologies in Turkey.

The construction of Turkish modernisation and nationalism is central to western thought. However, the depiction of Turkish identity has been carried out against an image of the west in which the west is a profound player in the formation of nationalism. Western modernity is the prototype for all modernities and functions as an 'other' for alternative modernities. Parta Chatterjee claims that western modernity has a strong role in eastern nationalist thought. He cites Edward Said's book Orientalism, commenting that Said has shown how the post-enlightenment age in Europe produced an entire body of knowledge in which the 'orient' appeared as a system of representation, formed by sets of forces that brought the orient into western learning, western consciousness and, later, the western empire. Orientalism is based on the distinction between 'orient' and 'occident', paving the way for the emergence of ontological and epistemological circumstances reflected in science, sociology and the military, and generating the hegemony of European culture all over the orient. Chatterjee categorises orientalism in two parts: thematic and problematic:

- thematic refers to:

An epistemological as well as ethical system which provides a framework of elements and rules for establishing relations between elements. ${ }^{3}$

- on the other hand:

Problematic consists of concrete statements about possibilities justified by reference to thematic. $^{4}$

If applied to nationalist thought, the object in nationalist thought is still the oriental, who retains an essentialist character delineated in orientalist discourses:

Only he is not passive, non-participating. He is seen to posses a 'subjectivity' that he can himself 'make'. In other words, while his relationship to himself and to others has been 'posed,

1 I would like to thank Ms. Ayșe Kaya for her contribution to this article.

2 Parlak, I and Ö. Kiliçarslan (2006) 'The west or the EU as "the other" from the perspective of national pride' South-East Europe Review for Labour and Social Affairs 9(3): 123-148.

3 Chatterjee, P (1986) Nationalist Thought and the Colonial World Delhi: Zed Books, p. 38.

4 ibid. 
understood and defined' by others, i.e. by an objective scientific consciousness, by knowledge, by reason, those relationship are not acted by others. His subjectivity, he thinks, is active, autonomous and sovereign. ${ }^{5}$

At the level of the thematic:

Nationalist thought accepts and adopts the same essentialist conception based on the distinction between the 'east' and the 'west,' the same typology created by a transcendent studying subject and hence the same 'objectifying' procedures of knowledge constructed in the postEnlightenment age of western science. ${ }^{6}$

As Chatterjee suggests, Eastern nationalism, or post-colonial nationalism, consists of paradoxes in itself in that it both accepts the values of the west and, at the same time, acts in a hostile manner. Eastern nationalism aims to transform the nation according to a model, which takes as an example the western model for itself, but it also wants to preserve and distinguish itself from the reference model. ${ }^{7}$ This situation exists in all post-colonial nationalist models. Indeed, the west has been taken both as a model and as an ideal; it is, at the same time, seen as an enemy. The state ideology, Kemalism, ${ }^{8}$ was also established in the same route explored by Chatterjee.

Kemalism, a modernisation project of Turkey, was set up against the negative memories of the Ottoman Empire and tried both to construct a unique nation-state model, by taking reference from the west, and to shroud the bad memories of the past. This dualistic understanding stems from the political socialisation process and is the

5 ibid.

6 ibid.

7 Kadioglu, A (1999) Cumhuriyet Iradesi Demokrasi Muhakemesi (The Republican Will and the Decision of Democracy) Metis: Istanbul, p. 37.

8 Kemalism's six pillars - republicanism, nationalism, statism, secularism, populism and revolutionarism-reformism - were the means for the elite to create a new nation. Nationalism was used to narrow the distance between nation and state. Statism 'was designated to promote capitalist industrialisation through import substitution politics carried out by the state, and gave expression to the politico-economic logic of the Kemalist elite' (Keyman, 1995: 104). According to Nur Betul Celik, the identification of statism with economics underlines the expression of 'despite the people but for the people or in the name of the people'. Liberalism and democracy lost their esteem in the eyes of the Kemalist elite, by which they were perceived as obstacles in the creation of a strong state, although fascism was a useful ideology for the elite: it fostered and legitimised one-party hegemony and prevented class struggle. Republicanism envisages the nation-state as 'impersonal rule', referring to national sovereignty through nationalism, while populism portrays the classless character of Turkish society, proposing an organic unit composed of professional groups, rather than classes, signifying the solidarity of the whole nation. Secularism and reformism, in the Turkish context, were the means to the construction of a national identity compatible with the other principles. Secularism meant the distinguishing of religion from the political sphere but, on the other hand, it also meant curbing religion in the Turkish context and isolating it in the private sphere (Celik, 2001: 49). Lastly, revolutionarism-reformism meant the formation of the nation and the implementation of reforms by the hands of the elite. These principles were firmly entrenched by the elite in the creation of a new nation-state. 
key in highlighting the subject, yet it is impossible to distinguish political socialisation from the ideology of the state. Kemalism determines political socialisation in Turkey, with the media and education the two main factors. Both these factors connect to 'power' and it is extremely difficult to distinguish them from their ideological framework. The state tries to direct both these factors in line with its ideology.

Socialisation is an:

Interactive process between the individual being socialised and the polity and the social agents that socialise him. ${ }^{9}$

Individuals absorb the beliefs, values and codes of behaviour of the society or social group and, as a result, are integrated into the institutional structures of that society or social group.

Socialisation is brought about by social, political, educational, economic and cultural institutions and the practices of these institutions. Political socialisation leads to political values, beliefs and codes of behaviour for individuals in a community, integrating them into that community. ${ }^{10}$ In the relationship between political socialisation and ideology:

Ideology is the means by which a society reproduces the relations that characterise it. Regarded as a corpus of ideas or a pattern of thinking, it is the cognitive residue of the practices of the social, cultural and economic relationships which sustain it. More dialectically, ideology is created and sustained through definite practices of work, communication and decisionmaking. ${ }^{11}$

Political socialisation is ideological in nature and leads to individuals assimilating ideological values and codes of behaviours. The dominant ideology normalises and legitimises the established order. Revolutionary ideology perceives the established order as illegitimate but the ruling ideology has major advantages in legitimising the established order. Through various institutions, such as education, media and the state, it can appear reasonable, moderate and rational to individuals, while these institutions disseminate relevant knowledge and codes of behaviour to individuals. ${ }^{12}$ It is concluded that individuals acquire the political ideology of the dominant ideology - in Turkey, the state's ideology - through its institutions.

In Turkey, political socialisation has a strong relationship with Kemalism. Turkish modernisation, which can be traced back to the late Ottoman period, aspires to shroud the past and acquire western civilisation. Its aim is to modernise society, with reference to the west, and forging a nation-state was part of this effort. The deterioration of the multi-ethnic structure of the Ottoman Empire due to ethno-nationalism within the empire, and the support for these movements of the imperial powers of the time, led to the emerging Turkish nationalism and to the perception of certain factors, notably

9 Dawson, R. E, K. Prewitt and S. Karen (1977) Political Socialisation Boston and Toronto: Little, Brown, p. 33.

10 Kaplan, I (1998) The ideology of national education in Turkey and its implications for political socialisation unpublished $\mathrm{PhD}$ thesis, Istanbul: Bogazici University, pp. 1-4.

11 ibid.p. 3.

12 ibid. pp. 1-4. 
the Christian minority and the west, as an 'other' or else in a xenophobic way. ${ }^{13}$ This perception is ironic, as the west (Europe) was both a target to reach and the 'sinister enemy' seeking to destroy the Ottoman Empire. This perception culminated in the Turkish Independence War and paved the way for the construction of a Turkish identity with reference to the west but opposed to the west. In World War I, the Ottoman Empire was defeated and the Sevr Treaty (11 May 1920), signed in the aftermath of the war between the Ottoman Sultan and the Italian, French and British governments, divided the Ottoman territories. This situation overlapped with the Turkish modernisation process, underway since the $18^{\text {th }}$ century, with Europe the reference point for the Ottoman and Turkish elite. The national Independence War (1920-1923) and the establishment of the Republic was a response to the Sevr Agreement and the subsequent occupation by the imperial powers of the time. ${ }^{14}$ According to Banu Helvacioglu:

One of the cultural legacies of the national independence war for present day Turkey has been the political and cultural representation of Europe as the enemy and a sinister force which threatens to break up Turkish national unity. The second objective of the national independence struggle was to break away from the political control of the Ottoman sultan. This goal was achieved by following the puzzling footsteps of the nation-state building in Europe. ${ }^{15}$

Helvacioglu underlines that the timing of Turkish modernisation overlapped with the occupation of the country by the imperial powers of the time. The construction of a Turkish identity and nation-state was realised with reference to this situation and paved the way to perceive Europe as both the 'ideal' and the 'sinister enemy'. In Turkish political socialisation, particularly in media and education, this background is clear. This reflects the discourse of political ideologies in Turkey throughout history.

International factors also bolster this vision. It is true that, for the Turkish elite, the west has always been a goal towards which to aspire. Turkey joined western institutions after World War II. During the Cold War, Turkey was the good ally for the west. After the Cold War, with the changing outlook in the international arena and as an outcome of the multi-polar structure of the world, Turkey started to redefine its position. In this new era, Turkey's foreign policy and domestic policy were determined by two western powers, the USA and the EU. The perspectives of European and American policies towards Turkey have been dominated by strategic considerations. Kramer remarks:

Turkey's relations with its western partners have profited from its location. Global or regional security interests and orientations of the United States and western Europe have been the driving forces of western policy and not, as many Turks like to see it, feelings of friendship or a sense of shared destiny, values or ideology. ${ }^{16}$

13 Belge, M (2002) 'Turkiye'de Senofobi ve Milliyetcilik' ('Xenophobia and Nationalism in Turkey') in T. Bora (ed.) Modern Turkiye'de Siyasi Dusunce: Milliyetcilik (Political Thought in Modern Turkey: Nationalism) Vol. 4, pp. 179-185.

14 Helvacioglu B (1999) 'The Paradoxical Logic of Europe in Turkey: Where does Europe End?' in European Legacy 4(3), p. 24.

15 ibid. p. 24.

16 Kramer, H (2000) A Changing Turkey: The Challenge to Europe and the United States Washington: Brooking Institution Press. 
After the eighties, the perception of these two powers towards Turkey has been reasonably constant. Concentrating on the geo-strategic position of the country, America's view of Turkey has focused on supporting the peace process in the middle east by expanding Turkish-Israeli co-operation and preventing Russia and Iran from marketing central Asia's energy resources. Europe's focal point on Turkey has also been its geo-strategic position, which can be defined as the country's function as a bridge to the Islamic world and central Asia or as a barrier against the growth of Islamic fundamentalism. However, its objectives have been mixed and uncertain when compared with the USA's aims for Turkey. Turkey has been outside the cultural boundary of Europe and its role has not been well defined in respect of the Union's geo-political boundary in the post-cold war era.

The US-Turkish relationship has always been determined by strategic considerations, with less concern for Turkey's democratic circumstances. There are several reasons for this, including the objectives of US foreign policy and the domestic political structure of the USA. However, a major aspect is the geographical distance between the USA and Turkey. The EU has, however, continued to consider Turkish politics after the eighties because political and economic instability in the country could negatively affect western Europe. Remembering the philosophy of Europeanisation - 'stability, prosperity, peace and community' - it can be seen that the EU's focuses on Turkey's stability falls within its own interests.

The EU does not have clear-cut views on Turkey in the post-cold war era. It has always defined Turkey as 'the bridge between east and west', culturally an 'outsider' but a 'semi-other' as regards the EU's geo-political boundary, while perceiving it both as a shield for Europe's security and as a bridge to central Asia and the middle east. In fact, this perspective prevents the EU having a coherent policy towards Turkey. On the other hand, the EU's Copenhagen criteria could not be effectively implemented by Turkey because of its 'transcendental' state heritage and lack of trust in the Union. These criteria were meant to bring about radical reforms in the state structure and a more robust embrace of state ideology. Moreover, the EU's role in the Kurdish issue and its actions, which have given priority to its security rather than to democracy and human rights in Turkey, is seen as imperialist. The institutional deficiencies of the EU, such as the divergent interests of its member countries in not forming a common foreign and security policy, combined with its actions towards Turkey, have created the feeling in Turkish public opinion that the 'imperial powers would exploit and conquer' Turkey. ${ }^{17}$ For example, after the 11 September attack, the EU delayed placing the PKK and the DHKPC on its terrorist list until comparatively late. All these factors result in a negative view of the EU in Turkish public opinion. Corneal Yasar Buyuk Anit suggests the stance of the EU has sown the seeds of 11 September terrorism on fertile lands. ${ }^{18}$

Looking at the history of Turkish modernisation, we can see that Turkish identity has changed in line with the actions of Europe. In fact, identity has a dialectical nature in that every identity excludes certain other identities in order to create, and renew, itself. Therefore, identity is not a stable concept and its content can change according to

17 See Ugur, M (1999) The European Union and Turkey: An Anchor/Credibility Dilemma Aldershot: Ashgate.

18 'Avrupa Terorde Hatali' ('Europe is Wrong on Terrorism') in Radikal 29 May 2002, p. 8. 
the boundaries set by others. Madan Sarup holds that identity in international relations is forged, and altered, through a process in which security, economic and sociological factors play a strong role. ${ }^{19}$ The disappointing actions of the west on the Cypriot and Kurdish issues have played a strong role in creating this new identity. ${ }^{20}$ This new brand of ideology was formed on the basis of distinguishing the Turkish cultural boundary from that of Europe, while Europe, which is seen as a concept of the west, became the "other ' in Turkish public opinion.

Both the vision of Turkish nationalism and international relations have strong effects on the different ideologies in Turkey and it is difficult to distinguish the discourse of these ideologies from these two phenomena.

\section{The west in different ideologies: prior to 1980}

The paradoxical image of the west and Europe stems from the modernisation project and from the discourses of different ideologies.

Turkish identity has always had a difficult relationship with the image of the west, particularly with western Europe. The history of the Europeanisation of Turkey can be traced back to the $19^{\text {th }}$ century, a concept referred to as westernisation since the beginning of the nineties. Indeed, the $19^{\text {th }}$ century witnessed the start of this paradoxical situation. On the one hand, the Ottomans struggled against the western powers; on the other, the elites tried to modernise the country by importing technology, which also led to the Ottoman Empire being influenced from the west. This paradoxical situation culminated and reached a peak with World War I with the elites who set up the Turkish Republic witnessing the occupation of Turkey by the western imperial powers. The Sevr Agreement was the turning point in the collapse of the Ottoman Empire and signified the surrender of Turkey to the western powers, with the concept of 'west' including 'colonialism, imperialism and exploitation' in the eyes of the Turkish elites. ${ }^{21}$ The elites placed a distance between Turkey's Ottoman past, including Islam, and themselves, and changed the direction of Turkey's future to the west, trying to create an identity of 'westerner but not pure westerner'. Helvacioglu puts it thus:

Just as much as the cultural construction of Turks, 'Islam' and 'orient', have been instrumental in the self-constitution of European identity, the cultural constructs of 'Christian Europe,' 'European civilisation,' 'Europe as a symbol of western progress,' 'Europe as a western ally' and 'Europe as a sinister enemy force' have been used in shaping the national cultural identity of Turkey. ${ }^{22}$

19 Sarup, M (1996) Identity, Culture and the Post-Modern World Edinburgh: Edinburgh University Press, p. 14.

20 Yavuz, H (2001) 'Degisen Turk Kimligi ve Dis Politika: Neo-Osmanliciligin Yukselisi' ('Turkish Identity and Foreign Policy in Flux: The Rise of Neo-Ottomanism') in S. Calis et al. (eds.) Turkiye'nin Dis Politika Gundemi: Kimlik, Demokrasi ve Guvenlik (The International Political Agenda of Turkey: Identity, Democracy and Security) Ankara: Liberte, pp. 39-40.

21 Helvacioglu, B op. cit. p. 29.

22 ibid.p. 24. 
Turkish identity was forged against the backdrop of the invasion of the country by the western powers during World War I:

There is an aim to harden the national consciousness within a political project (1918-1923) of a rescued state, which experienced a vanishing process. ${ }^{23}$

This myth was bolstered by enlightenment ideals such as civilisation, progress and anti-Ottomanism in the early Republican period. Ataturk was opposed to the imperialist policies of the west, but:

Supported the main principles of national and universal freedom and secularism within the context of promoting western civilisation in Turkey. ${ }^{24}$

The meaning of the word 'Turk' between 1923 and 1940 must be closely scrutinised to understand the tension between civilisation and the imperial powers. To evaluate the word, one must look at Kemalist history in this era, which stressed four points:

- firstly, Islam was a weak element in the word 'Turk,' as the history of Turks could be traced back to BC, the Hittite era, when Turks brought civilisation to Europe

- secondly, the tension between Turks and Europe was clear

- thirdly, there was an effort to prove that Anatolia had always belonged to the Turks, traced back in history to BC

- lastly, the crucial point in Kemalist writing was the break by Turks from Arabs who 'had betrayed Turks in the war' and the tension within Europe, predominantly with the Greeks. ${ }^{25}$

Kemalism itself, but also other ideologies on the left and the right, mostly derived from Kemalism, had problems with Europe and the west. Kemalism directly influenced these other ideologies. According to Culhaoglu, the left, which does not consist of social democrats, can be categorised into three periods: the first era was 1920 to 1960; the second from 1960 to 1980 ; and the third 1980 and thereafter. ${ }^{26}$

To understand the Kemalist influence, the first two periods may be briefly considered. According to Culhaoglu, in the first period there were no sophisticated terms like 'the west', 'modernisation' or 'westernisation' in left-wing discourse. Rather, they stressed bourgeois revolution. They perceived modernisation not as an independent process, but rather as a process dependent on Republican reforms which would develop capitalism and its understandings in law, society and the economy. In this era, Marxists faced a dilemma: they argued over whether, to reach communism as a goal, it would be better to generate the conditions of capitalism and its understand-

23 Milas H (2001) 'Being Able To Be A Part of Europe' in Modernity and Multiculturalism Istanbul: Iletisim Yayinlari and Helsinki Yurttaslar Dernegi, p. 169.

24 Helvacioglu, B op. cit. p. 24.

25 Copeaux, E (1998) Turk Tarih Tesinden Turk Islam Sentesine (From Turkish History to Turkish Islamic Synthesis) Istanbul: Tarih Vakfi Yayinlari, p. 37.

26 Culhaoglu, M (2002) 'Modernlesme Batililasma ve Turk Solu' ('Modernity, Westernisation and the Turkish Left'), in U. Kocabasoglu (ed.) Turkiye'de Siyasi Dusunce, Modernlesme ve Baticilik (Political Thought in Turkey, Modernisation and Becoming Westernised) Istanbul: Iletisim yayinlari, Vol. 3, p. 173. 
ings, so as to carry out a class struggle in real terms, like in Russia, or whether it would be better to transform the system based on populism and the restriction of private property, without first generating capitalist conditions in Turkey. The left, in this era, identified itself with Kemalism and used the concepts of civilisation and progress, with an image of the west similar to that in Kemalism. ${ }^{27}$

The next generation wanted to define society according to their ideals and on the basis of Marxist discourse. Unlike the first period, Marxist terminology was distinct from Kemalism, as Kemalism started to lose energy and take on universalist tones. However, the left did not entirely separate from Kemalism as some members from the earlier generation were still alive and constituted the second era together with the next generation. Some left-wing elites would become ideologues or specialists of the state. For example, some members of the Turkish Communist Party would set up 'Etibank' and 'Sumerbank': both state monopolies. Their perception of the west was involved and they encouraged 'third worldism' in which the ideals of Leninism and Maoism were strongly supported. ${ }^{28}$ The left aimed at reaching modernisation without westernisation and the rejection of the liberal economy, embodied in the image of the west, was a major element in their discourse. In 1963, the Association Agreement with the EEC was signed by a disappointed Turkish Workers Party - a Marxist Party. The disappointment of Marxist intellectuals stemmed from their scepticism about Turkey's integration into the EEC, as they thought Turkey could not travel this path with the west due to the different historical evaluations and the lack of a bourgeois class. ${ }^{29} \mathrm{Ali}$ Gevgili writes:

In Turkey it is the case that the outer appearance of Mr. European is usually taken into consideration and the whole chain of social, economic and historical determinants ... lying beneath the appearance are forgotten. ${ }^{30}$

Left-wing Kemalists, ${ }^{31}$ paradoxical about Europe and the west, included founders of the Turkish Republic such as Mustafa Kemal and Ismet Inonu. These elites were involved in the national independence war and, at the same time, were agents of Turkish modernisation. The reform process was synonymous with westernisation, but they were concerned about the effects of European culture on local culture. The west had both good and bad features, with the good sides being technology and industrialisation, and the bad sides the societal, cultural and, sometimes, the political values ${ }^{32}$ of the west. ${ }^{33}$ This made Europe the 'ideal' to reach but, at the same time, western-ori-

27 ibid.pp. 173-176.

28 Culhaoglu, M op. cit. pp. 171-187.

29 Nas, C 'Turkish Identity and The Perception of Europe' in Marmara Journal of European Studies 9(1), pp. 183-184.

30 ibid. p. 184.

31 Left Kemalism currently corresponds to social democracy. The CHP represents social democracy.

32 The state modelled society in Turkey by shrouding the Ottoman past and erasing Islam from the public domain, with the Ottoman and Islam elements considered uncivilised and anti-modern. The political formations outside state control were also controlled and eradicated by the state while western values, such as liberalism, socialism and class struggle, were suspicious. 
ented values were viewed suspiciously. Mustafa Kemal expressed his suspicion at the Lausanne conference:

Without giving importance to east and west, can we survive with our own dynamics?... The best policy is to rely on ourselves. ${ }^{34}$

A good example of the cultural distinction between Europe and Turkey was an article in Cumhuriyet, established in 1924 by Mustafa Kemal and located on the Kemalist left. ${ }^{35}$ The founder of the newspaper, Yunus Nadi, wrote an article about the Miss Universe contest in 1929, observing that Turkish women had reached the same level as their female western counterparts. ${ }^{36}$

Past experiences, derived from the Ottoman period and the national Independence War, made Turkey's relationships with the world, in the early years of the Republic, mainly isolationist, with foreign policy being based on the maxim 'there is no friend to the Turk than the Turk himself'. Post-World War II, Turkey played a role in reconstructing Europe, becoming a member of the OECD (Organisation for Economic Cooperation and Development) in 1948, the Council of Europe in 1949 and NATO in 1952. Accession to NATO was presented, and perceived, as a great victory for the government, the Democrat Party and for the opposition, the Republican People's Party. ${ }^{37}$

However, the struggle between the Democrat Party and the Republican People's Party led Republicans to criticise the Democrats for coming under the sway of the US. Cumhuriyet, in the Democrat Party era, blamed the DP for transferring a 'San Francisco type of democracy'38 to Turkey and destroying Ataturk's Republican regime, signifying that, if the Democrat Party did not promote and protect the principles of Kemalism, then the multi-party system could not flourish and gain strength. ${ }^{39}$ The important point to note here is that San Francisco has negative connotations, engendering negative perceptions of the western (San Franciscan) style of democracy. Thus, Turkish nation-state identity was still constructed against the west, but the signing of the Association Agreement in 1963 confirmed Turkey as a European country..$^{40}$ The Republican People's Party considered that:

33 ibid.p. 180.

34 Kasancigil, A (2002) 'Anti-Emperyalist Bagimsislik Ideolojisi ve Ucuncu Dunya Ulusculugu Olarak Kemalism' in A. Insel (ed.) Turkiye'de Siyasi Dusunce: Kemalism (Political Thought in Turkey: Kemalism) Istanbul: Iletisim yayinlari, Vol. 3, p. 240.

35 After the new interpretation of Kemalism, which co-ordinated Kemalism with the Turkish-Islam synthesis, the newspaper and the writers were opposed to this new interpretation of Kemalism. Some writers were placed in jail because of their thoughts, including the Editor, Ilhan Selcuk.

36 Erten, B. and G. Dogan (2002) 'Cumhuriyet'in Cumhuriyeti' ('Republic's Cumhuriyet') in A. Insel (ed.) Modern Turkiye'de Siyasi Dusunce: Kemalism (Political Thought in Modern Turkey: Kemalism) Istanbul: Iletisim yayinlari, Vol. 3, p. 503.

37 Nas, C op. cit. p. 182.

38 This concept was used sarcastically, indicating foreign, not native.

39 Erten, B. and G. Dogan op. cit. pp. 506-509.

40 Nas, C op. cit. p. 182. 
It was an inevitable decision for Turkey, a country which is situated on two continents but which, in mentality and civilisation, is included in the western world. ${ }^{41}$

The leader of the party, Ismet Inonu, at the ceremony of the signing of the Agreement, said:

With this Agreement we are convinced that we have transcended a serious stage in Turkey's route to westernisation - behaviour that had been made into a national policy by our beloved Ataturk. $^{42}$

In the 1970s, Turkey tried to promote socio-economic development and industrialisation by way of import substitution. The perception of the EEC by Kemalists was determined by the economic effects of accession for Turkey. Unlike the Kemalist right, the Kemalist left thought that the acceptance of western democracy did not mean accepting everything the EEC proposed. Turkey's acceptance of the EEC's economic proposals without analysing their effects and the extension of the transition period for adjusting the economy according to EEC principles was thought likely to damage the Turkish economy. ${ }^{43}$ However, the anti-imperialist stance of the Republican's People Party continued in its political discourse. Bulent Ecevit, as the head of the party and Prime Minister of Turkey, defended 1920s Kemalism as a concept which safeguarded the superiority of the Turkish nation, radical secularism and the cultural assimilation of Kemalism. For him, the Turkish nation was a whole that could not be separated, with external players, like the international oil companies and the western countries wanting to exploit Turkey and the middle east, discussing the different nationalities in Turkey. ${ }^{44}$ In the seventies, to be in the west was 'ideal', but the west, based on economic relations, was still the 'other' in the eyes of the Kemalist left.

Right-wing Kemalism in Turkey also had a difficult relationship with the west. The cadres of the Kemalist right, represented by the Democrat Party (DP) (1950 to 1960), the Justice Party (AP) (1961 to 1980) and the Trust Party (GP) (1967 to 1980), were also formed by ex-members of the Republican People's Party (CHP) and they were strongly influenced by the principles of Kemalism. Between 1940 and 1960, the polarisation between the central right and the left, embodied in the DP and CHP, was not based on Kemalism but rather on the positive approach of the DP to religion, the US and the enlargement of the free market. ${ }^{45}$

It is not surprising that the cadre of the Kemalism right also came from the Republican People's Party, while some prominent leaders of the Democrat Party, such as

41 Cited in ibid. p. 183.

42 Cited in ibid.

43 Tekeli, I. and S. Ilkin (1993) Turkiye ve Avrupa Birligi: Ulus Devletini Asma Cabasindaki Avrupaya Turkiye' nin Yaklasimi Ankara: Umit Yayincilik, pp. 57-58.

44 Bosarslan, H (2001) 'Bulent Ecevit' in A. Insel (ed.) Modern Turkiye'de Siyasi Dusunce: Kemalism (Political Thought in Modern Turkey) Istanbul: Iletisim, p. 460.

45 Bora, T. and Y. Taskin (2001) 'Sag Kemalism' ('Right Kemalism)' in Insel A., (ed.), Modern Turkiye'de Siyasi Dusunce: Kemalism (Political Thought in Modern Turkey) Iletisim, p. 531. 
Celal Bayar, were friends of Mustafa Kemal. The Kemalist right had the same strong two elements in their discourses:

- firstly, the perception of autonomous political formations as a threat

- secondly, hostility toward radical formations such as Islam and extreme nationalism. ${ }^{46}$

They continued the same discourse as the Kemalist left about the west, and there was an effort to merge universalism with essentialism. For example, Celal Bayar, a prominent representative of the Kemalist right, an ex-Prime Minister of Turkey from the DP and a friend of Ataturk, stressed the development of Turkey's international role in creating a new national identity. It is possible to see the paradoxical Kemalist logic in Bayar's discourse. His emphasis on western civilisation and leaning to the west, by grasping the values of Kemalism and the feelings of the nation, was a reflection of this dual thinking. Bayar thought that the inclination towards universal civilisation and modernity would lead Turkey to a hegemonic role in the international arena. His essentialist perspective is based on the denial of adverse experiences, like socialism and liberalism, in the west, and on the uniqueness of Turkey. The Kemalist right put economic specialism, pragmatism, progress and development at the forefront of modernisation. ${ }^{47}$

The discourses of the Kemalist Right were similar to the Kemalist left until the 1960s, despite the clash between them. ${ }^{48}$ After the sixties, with the rise of communism, the Kemalist right slightly changed its discourse into a Turkish-Islamic synthesis, which began to show its power in the Turkish political and social arena. ${ }^{49}$ An outcome of this process was that Islam and nationalism became major elements in the discourses of the Kemalist right and also led Islamism and nationalism to appear in the political sphere as separate political parties. Islamism and nationalism melted into the ideology of national conservatism before 1970 and were not separate political ideologies. The Islamists were represented by The Party of National Order (MNP) and the nationalists by the National Working Party (MCP).

Turkey's inclusion in western European organisations in the fifties, particularly in NATO, was perceived as a great victory by the Kemalist right. US 'Marshall Aid' to Turkey, against the communist threat, made the west a partner with Turkey. This, together with the signing of the Association Agreement, was interpreted as strengthening cultural ties with the west. ${ }^{50}$ The sixties brought the discourses of the Kemalist left and right closer due to the rise of the communist threat, while to be on the western side was an 'ideal' for right-wing Kemalists. The state elite - both the central left, the Kemalist left; and, on the right, the Kemalist right - took positions against communism. However, this did not mean the west's role as the 'other' vanished. The newlyestablished Republican Guven Party (Trust Party) (1967), on the right side of the spectrum of the political sphere, showed the transition inherent in this era. The Democrat Party collapsed and communism became the only 'other' for the Kemalist elite.

46 ibid. p. 531.

47 ibid. pp. 531-533.

48 Until the seventies, no ideology in Turkey could entirely distinguish itself from Kemalism.

49 The power of the Turkish-Islam synthesis culminated in the eighties.

50 Tekeli, I. and S. Ilkin op. cit. p. 46. 
The Trust Party, located to the right of the Kemalist stance, separated itself from nationalists, conservatives and Islamists by stressing national solidarity and the struggle against poverty. The party's perception of the west was based on the sensitive geographical location; the external threat, predominantly communism; and the themes of rancour against Turkey in the west and in the world. ${ }^{51}$ Unlike Islamists and nationalists in the eighties and nineties, the Kemalist right did not make the ontological critics of east and west dichotomous, nor did it reject the west. The position of these parties' attitude towards the west was varied. After the fifties, the west signified economic prosperity, following relative economic growth in society. ${ }^{52}$ After the sixties and seventies, Islam was still perceived as a threat and an obstacle to the western-inspired progress, development and civilisation of the state.

Islamists were suppressed by the Kemalists in the early periods of the Republic. The forging of the new nation-state paved the way for removing Islam from the public sphere. Nationalism, or pan-Turkism, was relatively free from state suppression, following the overlapping discourses of nationalists and the Kemalist elite. However, this convergence deteriorated in 1944 due to international factors and many nationalist elites were imprisoned. After 1945, and during the cold war, these two ideologies again came to the fore in the political sphere due to the communist threat. The state allowed these movements into the political domain on condition they accepted the boundaries of Kemalism, formed by nationalism and secularism..$^{53}$ Both ideologies borrowed elements of their discourses from each other due to the Kemalist influence. For example, the pro-Islamist party, the National Order Party, used the term 'national', while Islam played an important role in the discourses of nationalists. Islam and nationalism basically merged under the name of national conservatism, a Turkish-Islamic synthesis, in the seventies, although their discourses were vague. ${ }^{54}$ According to Bora, the reason was the recent formation of the nation-state in Turkey ${ }^{55}$ which allowed the state to be a powerful player at the beginning of the nation, and, like most movements, Islam and nationalism were curbed by the state, with ideologies within set boundaries. These ideologies were nurtured by each other in evaluating the ontology of west and east. Under careful scrutiny, the west was placed as an 'ideal' as its technological scientific side was appreciated but, on the other hand, it was perceived as the 'other'. The thoughts of Peyami Safa and Nurettin Topcu very clearly displayed the perspectives of this ideology, national-conservatism, between 1930 and 1960, in the sense that both these thinkers were of key importance in the thoughts of Islamists and nationalists.

51 Bora, T. and Y. Taskin op. cit. pp. 534-553.

52 Erten, B. and G. Dogan op. cit. p. 508.

53 Akgun, B. and Saban H. Calis (2002) 'Turk Milliyetciliginin Terkibinde Islamci Dos' ('The Degree of Islam in the Construction of Turkish Nationalism') in T. Bora (ed.) Modern Turkiye'de Siyasi Dusunce: Milliyetcilik (Political Thought in Modern Turkey: Nationalism) Iletisim, pp. 594-597.

54 Islamists have tried to distinguish Islam from nationalism and attempted to interpret the new versions of Islamism after the eighties, but the military intervention on 28 September 1997 obstructed this.

55 Bora, T (1998) Turk Saginin Uc Hali: Milliyetcilik, Muhafasakarlik and Islamcilik (Three Conditions of Turkish Right: Nationalism, Conservatism and Islamism), Istanbul: Iletisim Yayinlari, pp. 130-133. 
Peyami Safa was a conservative thinker who addressed religion, although this was never a dominant aspect of his ideology. Safa sought to establish a new civilisation for Turkey which was, culturally, between east and west. He thought that, even though eastern mysticism gave rise to a blind religious belief, western civilisation's scientific rationale created a similar outcome in relation to science, with scientific blindness equalling nihilism. Turkey had a chance to overcome this difficulty if it preserved its eastern senses. In his later studies, Safa stressed the thought that secularism was not the essence of the west, and held that a revolution of this nature did not mean becoming an enemy of tradition, but he still perceived Islamists as a danger. ${ }^{56}$

Nurettin Topcu addressed Islam more directly than Safa. He tried to find a unique essentialist theory about east and west which he referred to as Anatolia nationalism and socialism. This theory is roughly based on the solidarity of society which, in turn, was based on Islam and nationalism. Topcu and his school gave the existence of the nation an important place and considered national ties merged with religious ones. Topcu perceived modernisation as psychologically complex because western civilisation was formed from states which shared common values and traditions while Turkey did not share such values. For this reason, Topcu proposed that Turkey belonged amongst eastern civilisation, with which it shared common values. Topcu criticised the west for the dominance of materialism over morality and told it that the core of materialism had destroyed the moral heritage of other nations. Paradoxically, he did not see the west as a purely materialistic concept, perceiving Christian spiritualism and materialism as constantly struggling with each other. ${ }^{57}$ Topcu was against industrialism, capitalism, big investment, Jews, cosmopolitanism, riches and democracy. ${ }^{58}$ Under scrutiny, it is possible to see common points between his discourses and recent Islamist-conservative discourses, but Topcu criticised Islamists on the premise of denying the nation. Arabs who lived in the desert had a different perspective of Islam to Anatolian village dwellers. For him, Islam was important in forging the nation and to separate Islam from the Turks meant to make people soulless. ${ }^{59}$

In the depicted framework about Islamists and nationalists, participation in the EEC posed a threat to traditional and religious values. An ideologue of the nationalist right, Sabahattin Saim expressed his perception thus:

Considering that the ultimate aim of the Common Market is to construct a Union of European States, should we let Turkey become a province in this Union? ... If Turkey enters the Common Market, the Turkish nation will be surrendered to imperialist Christian-western culture. The most dangerous imperialism is cultural imperialism. As Turkish nationalists, we are against the Common Market. ${ }^{60}$

Nejmettin Erbakan, the leader of the pro-Islamic Party of National Order, considered the Common Market to have been formed by Catholic countries. Turkey's accession to the Common Market would lead Turkey to be assimilated in a Christian Europe. Turkish history, societal structure and life perspective were different from those

56 ibid.p. 77.

57 Gundogan, A. O (2000) 'Nurettin Topcu' in Dogu Bati 3(11): 90-92.

58 Bora, Top. cit. p. 91.

59 Bora, T op. cit. p. 93.

60 Ilkin, S. and I. Tekeli op. cit. pp. 94-95. 
of Europe, which prevented it being a member of the Common Market. Moreover, he thought that the Treaty of Rome ended the sovereignty of countries and that Turkey would lose its sovereignty by entering under the rule of the Commission of the EC, which would allow Turkey to be exploited by the EEC. ${ }^{61}$ Different to the Kemalist right and left, both ideologies criticise Europe in the ontological sense.

The problematic place of the west in Turkish thought is highlighted in the essentialist future of Turkish political thought, arising from the theme of the 'uniqueness of the Turkish nation and Islam', sometimes anti-western and sometimes pro-western sentiment and the place of the EU/EEC in this vague atmosphere.

\section{The EU in different ideologies: the post-1980 period}

The eighties witnessed the start of a new era for Turkey and both domestic and international factors determined perceptions of the EU. The 1980 military intervention, aimed at suppressing left and right movements in Turkey, and the statist elite envisaged a restoration within the political sphere of the Turkish-Islamic synthesis, the ideology of which became the key in political and public institutions. ${ }^{62}$ This development led Kemalism to be interpreted in line with the Turkish-Islamic synthesis which, in turn, made politics more nationalist and Islam an important element in the political sphere. This period preserved the relationship of Turkey with the west but also heralded the intensification of anti-westernisation. ${ }^{63}$

International factors also affected the perception of the EU in the political sphere. After the 1983 national elections, Turkey was integrated with globalisation in an economic and political sense. The country's position vis-à-vis the USSR lost its strategic importance for the EU and the latter could not place Turkey within the architecture of the new European borders. The state and the political elite came to realise they were not the only players in their domestic politics; EU countries interfered in the domestic politics of the country, particularly on human rights issues. The state fell into a paradoxical situation, as it was in the last period of the Ottoman Empire. The country's application for full membership was rejected by the Union, but the political and state elite could not act freely due to the interference of the EU. The country had shifted a degree of its sovereignty to the EU and the supra-national organisations but was not accepted into EU membership. The erosion of the nation-state by the effects of globalisation, and the indispensable role of the EU in Turkey's political and economic life, paved the way for the differing ideologies to fall into a paradoxical logic about the EU - as the 'ideal', but also as the 'other.'

61 ibid.p. 116.

62 According to the Turkish-Islam synthesis, the cultural politics of the state must preserve the principles of national culture set up on the basis of Islamic values. The relationship with the west should be downgraded and allowed to continue only in the economic context. The state and the public institutions were designed on the basis of the Turkish-Islamic synthesis. The state opened many pastor and preacher schools (religious universities and high schools) and religious lessons became compulsory in primary and higher education.

63 Taskin, Y (2001) '12 Eylul Ataturkculugu ya da Bir Kemalist Restorasyon Tessebusu Olarak 12 Eylul' ('The Kemalism of 12 September, or 12 September as an attempt of Kemalist restoration') in A. Insel (ed.) Modern Turkiye'de Siyasi Dusunce: Kemalism (Political Thought in Modern Turkey) Iletisim, p. 571. 
In this section, I continue with an analysis of perceptions and evaluate how the different political ideologies perceive Europeanisation. The perception of Islamists, the right and the left about the EU are the focus of the following sub-sections.

\section{Islamist identity}

Most Islamists ${ }^{64}$ in Turkey approach Europe, the west and the EU suspiciously, based on the emphasis they place on the religious, cultural and historical differences. The Ottoman Empire, the representative of the Muslim community and Islam, had clashed with Europe over hundreds of years and Crusades had been mounted against the Ottoman Empire. The EU, as a representative of Christianity and a continuation of western imperialism, is considered responsible for demolishing the Ottoman Empire. Islamists oppose the EU from two viewpoints: the first is the current and impending erosion of Islamic and Turkish elements in Turkey; the second is a fear of the erosion of the nation-state through EU integration.

For Islamists, the EU is delaying Turkey in the EU negotiations so as to undermine Turkey's good relationships with the Balkans, the Turkic republics and the middle east. Turkey has not finished the nationalisation process, yet the EU tries to arouse micro-nationalism and, if Turkey shifts its sovereignty to the EU, the country would be broken into pieces in the process. Islamists consider religion the cardinal parameter in determining identity and, in this sense, Christianity is the first and foremost element of European identity; in this context, there is no place for Islam in Europe. ${ }^{65}$

Islamists in Turkey have been opposed to the EU since the seventies on the grounds that it is a Christian club. They consider the EU a political integration rather than an economic integration. The Welfare Party, the only party opposing full membership of the EU, considered the EU to be acting on the advice of Pope Pius XI and that the EU's action in not accepting Turkey was based on this. Abdullah Gul, ex-deputy of the Party and responsible for foreign relations, explained its unwillingness to enter the EU by stressing Turkey's cultural and religious differences. ${ }^{66}$

According to the well-known Islamic writer, Abdurrahman Dilipak, all states and societies are established on the basis of common historical, sociological and political backgrounds. In this context, there are huge differences between Turkey and EU countries. EU membership violates the principles of the Turkish constitution, which stresses the sovereignty of Turkey. Dilipak likens the EU process to the continuation of the Tanzimat in the sense that the Tanzimat reforms divided the unity of Muslims and destroyed the Caliphate, uniting all Muslims under the authority of Turks. Therefore, EU integration would bring backwardness and poverty to Turkey instead of civilisation and progress. ${ }^{67}$ According to Huseyin Inanc, some Islamists warn of the danger of EU integration, arguing for a comprehensive evaluation of European inte-

64 Islamist ideology is not uniform and some sectors also support EU entry. Mostly, however, Islamists were against accession to the EU before 28 February 1997.

65 Inanc, H 'Avrupa Entegrasyonu Surecinde Turkiye'nin Kimlik Problemleri' ('The Identity Problems of Turkey in European Integration') in Dogu Bati 6(3): 196-197.

66 Dagi, I (1998) Kimlik, Soylem ve Siyaset: Dogu Bati Ayriminda Refah Parti Gelenegi (Identity, Discourse and Politics; The Welfare Party Tradition at the Junction of East and West) Ankara: Imge Yayinevi, pp. 52-54.

67 Cited in Inanc, H op. cit. pp. 197-198. 
gration. Like the negative outcome of the Tanzimat, from which the non-Muslim minority, the state elite and the church gained benefit, some politicians, bureaucrats and intellectuals rely on the EU and expect to gain personal benefit from entry to it, in contrast to poor people who devote themselves to their religion and their nation. ${ }^{68}$

However, the perspective of Islamists began to change in the late eighties, a process which reached its peak after the 28 February 1997 state intervention against the Welfare Party in particular and the Islamic movement in general. Islamists wanted to liberalise the public domain through the principles of the Copenhagen criteria which they used in their discourse, with the EU acting as a means to support them in realising their ideas within the public sphere. In this context, and in the eyes of Islamists, democratic elements in Europe make the EU an inevitable player in the democratisation process of Turkey. After 28 February 1997, Abdullah Gul and ex members of the Saadet (Virtue) Party, ${ }^{69}$ together with the current foreign minister of Turkey from the Justice and Development Party (AKP), began to support Turkey's entry into the EU in the hope that membership would prevent another coup..$^{70}$ Recai Kutan, the head of the Virtue Party and an ex-deputy of the Welfare Party, stated that:

The former EU was a Christian Club but today it is not. ${ }^{71}$

Banu Helvacioglu explained this change as follows:

Within the confines of dualist thinking and oppositional politics the cultural constructs of "colonialists,' 'imperialist' and 'Christian' Europe have now been transformed into 'Europe as a centre for democracy and human rights' as well as a political ally against the internal enemy which is the centralised power structure of the state and the Turkish military. ${ }^{72}$

In brief, Islamists were ontologically opposed to the EU on the basis of the religious differences and the historical confrontation with Europe. They believed that the west, embodied in the EU, would like to destroy Turkey by integrating Turkey into the EU. However, the relationship with the statist elite, resulting in the military intervention of 28 February 1997, compelled Islamists to observe the principles of the Copenhagen criteria: Europeanisation began to mean the liberalisation of the public domain. In brief, the EU came to mean both the 'other' and the 'ideal' for Islamists after 28 February 1997.

\section{Identity on the right and the EU}

The right in Turkey has differing views on Europe. In this sub-section, I evaluate the right in two categories: the centre right; and the far right, represented by the National Action Party (MHP). In the EU debates, the National Action Party was the only party which totally opposed the policies of the EU and entry to the EU through an acceptance of the Copenhagen criteria.

68 Cited in ibid. p. 200.

69 After the banning of the Welfare Party, the same cadre of the Party established the Virtue Party.

70 Helvacioglu, B op. cit. p. 29.

71 Radikal 8 June 2002.

72 Helvacioglu, B op. cit. p. 29. 
The centre right in Turkey also has differing views on the EU and Europe. From the perspective of the right, there is a cultural gap between Europe and Turkey which should be protected despite Turkish modernisation and, in this regard, Turkey has always been the 'other' for the EU. In this ideology, western Europe still continues its undercover policies aimed at weakening Turkey ${ }^{73}$ while, at the same time, the EU indicates economic prosperity and stability. The centre right appreciates the reinforcement of democratic rights and freedoms through the adoption of EU regulations and principles. For example, an MP from the Motherland Party, Samil Ayrim, says:

By means of the Europeanisation project we will obey democracy and human rights. In industry and agriculture we will upgrade our technology. There will be technological transformation. ${ }^{74}$

However, it opposes some policies of the EU, particularly the minority policies reinforced by the Union. The myth that the imperial powers still continue their policies and act unjustly comes to the fore. In my field research, a former minister responsible for the foreign relations of the 'Motherland Party', Bulent Akarcali, said:

Institutionally and physiologically the EU has the means to provide stability in Turkey. By means of EU membership Turkey will get rid of the physiological loneliness... The EU approaches the Kurdish problem by itching. ${ }^{75}$ However, it currently realises the Kurdish problem in particular cannot be solved without solving the democratisation problem of the country in general. Turkish citizens cannot be protected by minority rights, a concept essentially imposed by the UK who did not believe, in the 1920s, that Turkey could be a democratic country. It thought to protect the Armenian and Rum minorities by means of minority rights. However, in the Lozan Agreement, an Istanbul rabbi told the European powers that the Jews in Turkey did not want a status of minority rights. Britain tried to impose the social technology of the 1920s but this did not function. The way to solve the Kurdish problem is through democracy. The EU has not make an effort to solve the east Anatolian problem, nor has it made an effort to promote the south-east Anatolian project. ${ }^{76}$

The image of the strong nation-state is powerful for centre right parties, which also stems from the Kemalist structure of the political sphere in which they function as agents of the state. In this sense, in international problems, such as the Cyprus issue, these parties act as if they are representative of the state. The recruitment of higher-ranking bureaucrats to these parties - from both the military and civilian bureaucracies - ties these parties firmly to the state. Umit Cizre succinctly clarifies in his article the connection between state and party. ${ }^{77}$ In the beginning of her period as prime minister, Tansu Ciller, ex-leader of the True Path Party (Dogru Yol Partisi), approached the solution to the Kurdish problem by seeing it in the context of peaceful solutions, including the granting of cultural rights. With the escalation of the confrontation with the PKK, the Ciller stance on the democratisation of Turkey changed:

73 Inanc, H op. cit. pp. 195-196.

74 Interview with Samil Ayrim, MP in the Motherland Party.

75 'Itching' refers to provoking or helping to arouse.

76 Interview with Bulent Akarcali, MP of the Motherland Party.

77 Cizre, U (2002) 'From Ruler to Pariah: The Life and Times of the True Path Party' in B. Rubbin and M. Heper (eds.) Political Parties in Turkey London-Portland: Frank Cass, p. 92. 
Connected with the Kurdish problem, Ciller's approach to the military represented a radical departure from the traditional party line. As she hoped to score a political victory on the Kurdish issue by military gain, she abandoned any pretence of supporting civilian control over the military. ${ }^{78}$

This structure of the political sphere, generated to a great extent by the principles of Kemalism, forced the centre right parties firmly to support the nation-state, making the EU the 'other' in political and physiological terms. The physiological background of the right, perceiving the EU as the 'other', combines with the structure of the political sphere and makes the EU the 'other' in the eyes of the whole centre right ideology.

The far right, as embodied in the National Action Party, draws a sharp distinction between Turkey and Europe. The party emphasises four points in its party programmes on the reasons it is opposed to the EU:

- firstly, the national sovereignty of Turkey will shift to the European Parliament and Turkey will lose power

- secondly, the nationalist character of the Turkish economy will be undermined in the integration process of the EU

- thirdly, the nationalist character of property rights will be lost

- lastly, the degeneration of socio-cultural identity will be accelerated. ${ }^{79}$

This rhetorical opposition is bolstered by the myth of a 'sinister enemy', or the 'other', which is powerful in its discourse and an image reinforced by reference to Ottoman and Turkish history. For example, nationalists liken the EU integration process and the Copenhagen criteria to the policies of the Ottomans towards the non-Muslim minority, enforced by the pressure of European powers to improve their lives. They also compare the customs union to the capitulation in the $19^{\text {th }}$ century. ${ }^{80}$ Like Islamists, they criticise the ontological concept of the west. In this stance, the Nationalist Action Party resembles the conservatives (Islamists). Ontologically, the Party uses religion and nationalism as instruments of resistance to universal secular assimilation. ${ }^{81}$ Nationalists have a tendency to create imaginary enemies to keep the nation's faith.

For Bora, nationalism has two facets: on the one hand, it has a humanist, civilian face; while, on the other, it has a chauvinist, racist and oppressive character. ${ }^{82}$ This tension is also seen in the views of the National Action Party. On the one hand, it wants to enter the EU; while, on the other, it opposes the EU and its values. In this paradoxical logic, the Party wants to enter the EU in order to become a power in the world architecture. The founder of this pro-nationalist Party, Alpaslan Turkes, wanted to enter the EU to create a 'great Turkey' and he accepted Turkey's entry into the customs union positively in the sense that the Turkic republics could integrate into Europe via Turkey. ${ }^{83}$ At the same time, the MHP perceives the Copenhagen criteria to be

78 ibid.

79 Inanc, H op. cit. p. 195.

80 ibid.p. 196.

81 Smith, A. D (1995) Nations and Nationalism in a Global Era Cambridge: Polity Press, p. 41.

82 Bora, T op. cit. pp. 98-100.

83 Findikci, A 'Helsinki Sirvesi Sonrasi Turkiye-Avrupa Birligi Iliskilerinde Yeni Olusumlar' (The New Formations in Turkey - the EU Relationship after the Helsinki Summit') in Mulkiye XXIV(222): 22. 
principles which weaken the organic relationship between state and society. ${ }^{84}$ The strong state principle of the Party will be eroded by the impact of the EU on the domestic politics of Turkey, which is of concern to the Party. ${ }^{85}$ The leader of the party, Devlet Bahceli, mentions that the reforms, represented as successful steps on the way to full membership of the EU, could bring instability to Turkey, ${ }^{86}$ fostering this perception by reference to the EU's actions. The MHP is opposed to the EU's stance in the Abdullah Ocalan situation, the EU's slow reaction in adding the PKK to its terrorist list after 11 September 2001 and its role in the Cyprus and Aegean problems. For these reasons, the Party has made the EU a major aspect of its policies and the sinister enemy, or 'other', of Turkey. It thinks the EU will destroy Turkey in the integration process, while nationalists nurture their identity against the image of the EU. The paradoxical logic of the Party can be vividly seen in the statement of the Vice-President of the Party, Sevket Bulent Yahnici:

... We have to enter the EU... The rights that the EU wants can destroy the country, as Turkey is not ready to realise these principles and the EU must understand this. The EU must understand how we have difficulty in honouring many of the principles. If they do not understand us and continue their mercilessness... it means the EU does not have goodwill. If the situation breaks up Turkey under the pretext of democracy, and we must enter the EU by giving up Cyprus 87

To sum up, the National Action Party wants to enter the EU in order to become a major power. On the other hand, it is not happy about the Europeanisation of Turkey, as the country would lose its sovereignty and its identity through the actions of the EU, seeking as it does to erode the power of the country.

\section{Identity on the left and the EU}

Perceptions on the left about the EU are not homogenous. For example, some sectors on the left oppose EU accession on the basis of losing sovereignty; others oppose the EU on the basis of Turkey being exploited by capitalism. Some criticisms are based on orthodox Marxist understanding, stressing the impossibility of Turkey's accession to the EU, but essentialism and Euro-scepticism may vividly be seen in their discourses. In this sub-section we evaluate the discourses of the left on the EU.

In some sectors of left ideology, European integration can not be accepted because of the Union's 'imperialistic' and supra-national structure. Many left-wing intellectuals are against EU accession on the basis of the shift of sovereignty of the country to the EU. According to Mumtaz Soysal, Turkey should not accept accession to the EU not only because of the country's sensitivity on national sovereignty and nationalism but also from the viewpoint that Turks are the only people who know their own needs

84 Nas, C op. cit. p. 187.

85 Cinar, A. and B. Arikan 'The Nationalist Action Party: Representing the State, the Nation or the Nationalists' in B. Rubbin and M. Heper (eds.) Political Parties in Turkey LondonPortland: Frank Cass, p. 35.

86 'One for its Partner, One for the EU' in Radikal 6 March 2002, p. 1.

87 Duzel, N (2001) 'Pazartesi Sohbetleri' ('Monday Chat') in Radikal 26 October 2001, p. 6. 
and can find appropriate solutions. ${ }^{88}$ There is a general fear of havoc as regards the national interests of the country arising from integration into the EU.

Some sectors on the left stress the impossibility of Turkey's economic integration with western European countries, arising from past experience and political and social differences. Many Marxist intellectuals think that Turkish economic development is historically different to that of western European countries and that a bourgeois class could not be created in the country. ${ }^{89}$ Mehmet Ali Aybar uses Marxist terminology and stresses that Turkey's integration with the EU means a transfer of the supra-structure of the west without a transfer of the infrastructure, a process which has little meaning. The supra-structure refers to the political system shaped by the industrial revolution, Greek-Latin culture and western philosophy; the infrastructure includes industry and the mode of production..$^{90}$ Another Marxist writer, Kazgan, supports these thoughts and also thinks that integration with the EU would negatively influence social stability and harmony. Kazgan points out the different historical evolution of Turkey and western European countries and thinks that the strong state tradition and Islamic values in the Ottoman Empire prevented the formation of a cultural and historical background similar to that of European countries; such a change to Turkey's civilisation would bring about the end of Turkish-Ottoman civilisation. ${ }^{91}$ These writers make the point that Turkey and the west are different civilisations and that the integration of these two civilisations is impossible.

Social democrats, the most powerful sector on the left, and left-wing liberals perceive Europeanisation in a positive way, but approach it cautiously. This sector accepts the dominance of the free market economy and liberal democracy in the world. For example, Ercan Karakas, a former deputy of the Republican People's Party (CHP) and the Social Democrat People's Party (SHP), argues that globalisation has heightened inequalities in the world; global and democratic solutions must be found to global problems while social democrats must support a Europeanisation project emphasising democracy, human and social rights. ${ }^{92}$ In this perspective, accession to the EU is the only way of entrenching democracy, a free market economy and human rights in Turkey. This sector of the left thinks that, without the inspiration of the EU's political culture, it is impossible to create a democratic state, while it also perceives that accession to the EU would maintain political pluralism in the country. For it, military intervention and political Islam can be controlled through accession..$^{93}$

Social democrats in Turkey, however, perceive the laws and regulations imposed by the EU to be unnecessary; the nation-state and nation-state dynamics are cardinal elements in their discourse. They see the EU as an important player in transforming and institutionalising the socio-economic and political structure of the country, but they give more importance to the formation of a democracy and a strong free market economy arising from the distinct dynamics in Turkey. For them, realising liberalisa-

92 Sever, M (2002) 'Solda Yeni Arayislar' ('New Seekings on the Left')' in Radikal 20 May, p. 4.

93 Inanc, H op. cit. p. 194. 
tion and democratisation without Turkey's own dynamics means that accession to European structures has little benefit for Turkey. ${ }^{94}$ This perception underlines the importance of nation-state dynamics. Instead of Europeanisation, social democrats and leftwing liberals propose the management of Turkey in line with universal values such as democracy, liberal democracy and human rights.

In summary, there are differing views on the left. Some think that EU accession means a loss of sovereignty and an abandonment of Turkey to imperialism. On the other hand, some think it impossible to 'Europeanise' Turkey on the premise of the different historical and social evolution. However, social democrats and left-wing liberals place strong emphasis on the EU, which they perceive as a stimulus in transforming Turkish politics and economics. However, they are anxious that the EU should not be the main player in transforming Turkey and that Turkey should rather transform itself through its own dynamics.

\section{Summary}

The paradoxical logic of the Turkish public stems from Turkish modernisation, traced back to the late Ottoman period overlapping World War I, which led Kemalism to the paradoxical logic of perceiving the west both as the 'ideal' and as the 'other.' All ideologies in Turkey see the west as an 'ideal' to be reached but, at the same time, as the ominous 'other'. It is possible to see essentialism in these ideologies which stress the uniqueness of Turkey and Turkish history and culture. After the late eighties lessened the importance of the geo-strategic position of Turkey, with the changing political characteristics restricting sovereignty, the EU began to demand changes in the country's domestic politics while, at the same time, being reluctant to accept the country into the Union as a result of the country's reluctance to realise the political and economic criteria determining its position in the new European architecture. This action re-created the paradoxical perception of the EU. In this context, Islamists considered this action as a loss of sovereignty and of Islam, resulting in a rejection of the EU. However, actions by the statist elite persuaded Islamists that the EU should be seen as a way of extending political freedom in the public sphere.

The right, particularly nationalists, perceive the EU as an imperial power which would diminish the power of the country but, at the same time, they stress the benefits of entering the EU in the sense that the country would belong to a group of powerful countries.

There are varied perceptions on the left about the EU but the strongest sector on the left, the social democrats, perceive the west as an essential player in transforming Turkish politics and economics. However, it approaches the EU with caution. The EU is not the main player in their discourse - that the country should transform its political and economic structure using its own dynamics - underlining the importance of nation-state dynamics.

All these ideologies stress the uniqueness of Turkey and perceive the EU both as the 'ideal' and as the 'other'. This is related to the political culture which is strongly connected to political socialisation.

94 ibid. 


\section{References}

Akgun, B. and Saban H. Calis (2002) 'Turk Milliyetciliginin Terkibinde Islamci Dos' ('The Degree of Islam in the Construction of Turkish Nationalism') in T. Bora (ed.) Modern Turkiye'de Siyasi Dusunce: Milliyetcilik (Political Thought in Modern Turkey: Nationalism) Iletisim, pp. 584-617.

Belge, M (2002) ‘Turkiye'de Senofobi ve Milliyetcilik' ('Xenophobia and Nationalism in Turkey') in T. Bora (ed.) Modern Turkiye'de Siyasi Dusunce: Milliyetcilik (Political Thought in Modern Turkey: Nationalism) Vol. 4, pp. 179-185.

Bora, T. and Y. Taskin (2001) 'Sag Kemalism' ('Right Kemalism') in A. Insel (ed.) Modern Turkiye'de Siyasi Dusunce: Kemalism (Political Thought in Modern Turkey) Iletisim, pp. 529-554.

Bora, T. (1998) Turk Saginin Uc Hali: Milliyetcilik, Muhafasakarlik and Islamcilik (Three Conditions of the Turkish Right: Nationalism, Conservatism and Islamism) Istanbul: Iletisim Yayinlari.

Bosarslan, H. (2001) 'Bulent Ecevit' in A. Insel (ed.), Modern Turkiye'de Siyasi Dusunce: Kemalism (Political Thought in Modern Turkey) Istanbul: Iletisim, pp. 458-476.

Chatterjee, P (1986) Nationalist Thought and the Colonial World Delhi: Zed Books.

Cinar, A. and B. Arikan (2002) 'The Nationalist Action Party: Representing the State, the Nation or the Nationalists' in B. Rubbin and M. Heper (eds.) Political Parties in Turkey London-Portland: Frank Cass, pp. 25-41.

Cizre, U (2002) 'From Ruler to Pariah: The Life and Times of the True Path Party' in B. Rubbin and M. Heper (eds.) Political Parties in Turkey London-Portland: Frank Cass, pp. 82-102.

Copeaux, E (1998) Turk Tarih Tesinden Turk Islam Sentesine (From Turkish History to Turkish Islamic Synthesis) Istanbul: Tarih Vakfi Yayinlari.

Culhaoglu, M (2002) 'Modernlesme Batililasma ve Turk Solu' ('Modernity, Westernisation and the Turkish Left') in U. Kocabasoglu (ed.) Turkiye'de Siyasi Dusunce, Modernlesme ve Baticilik (Political Thought in Turkey, Modernisation and Becoming Westernised) Istanbul: İletisim yayinlari, Vol. 3, p. 170-188.

Celik, N. B (2001) 'Kemalizm: Hegemonik Bir Söylem' (Kemalism: a Hegemonic Discourse') in A. Insel (ed.) Modern Turkiye'de Siyasi Dusunce: Kemalizm (Political Thought in Modern Turkey: Kemalism) Istanbul: İletisim Yayinlari.

Dagi, I (1998) Kimlik, Soylem ve Siyaset: Dogu Bati Ayriminda Refah Parti Gelenegi (Identity, Discourse and Politics; The Welfare Party Tradition at the Junction of East and West) Ankara: Imge Yayinevi.

Dawson, R. E, K. Prewitt and S. Karen (1977) Political Socialisation Boston and Toronto: Little, Brown.

Duzel, N (2001) 'Pazartesi Sohbetleri' ('Monday Chat') in Radikal 26 October, p. 6.

Erten, B. and G. Dogan (2002) 'Cumhuriyet'in Cumhuriyeti' ('Republic's Cumhuriyet') in A. Insel (ed.) Modern Turkiye'de Siyasi Dusunce: Kemalism (Political Thought in Modern Turkey: Kemalism) Istanbul: Iletisim yayinlari, Vol. 3, p. 501512. 
Findikci, A 'Helsinki Sirvesi Sonrasi Turkiye-Avrupa Birligi Iliskilerinde Yeni Olusumlar' ('The New Formations in Turkey - The EU Relationship after the Helsinki Summit') in Mulkiye XXIV(222): 7-70.

Gundogan, A. O (2000) 'Nurettin Topcu' in Dogu Bati 3(11): 90-92.

Helvacioglu, B (1999) 'The Paradoxical Logic of Europe in Turkey: Where Does Europe End?' in European Legacy 4(3): 18-34.

Inanc, H ‘Avrupa Entegrasyonu Surecinde Turkiye'nin Kimlik Problemleri' ('The Identity Problems of Turkey in European Integration') in Dogu Bati 6(3).

Kadioglu, A (1999) Cumhuriyet Iradesi Demokrasi Muhakemesi (The Republican Will and the Decision of Democracy) Metis: Istanbul.

Kaplan, I (1998) The Ideology of National Education in Turkey and Its Implications for Political Socialisation unpublished $\mathrm{PhD}$ thesis, Istanbul: Bogazici University, pp. 1-4.

Kazancigil, A (2002) 'Anti-Emperyalist Bagimsislik Ideolojisi ve Ucuncu Dunya Ulusculugu Olarak Kemalism' in A. Insel (ed.) Turkiye’de Siyasi Dusunce: Kemalism (Political Thought in Turkey: Kemalism) Istanbul: Iletisim yayinlari, Vol. 3, pp. 235-246.

Keyman, E. F (1996) 'On the Relations Between Global Modernity and Nationalism: The Crisis of Hegemony and The Rise of Islamic Identity in Turkey' in New Perspectives on Turkey 13: 93-120.

Kramer, H (2000) A Changing Turkey: The Challenge to Europe and the United States Washington: Brooking Institution Press.

Milas, H (2001) 'Being Able To Be A Part of Europe' in Modernity and Multiculturalism Istanbul: Iletisim Yayinlari and Helsinki Yurttaslar Dernegi, pp. 163-172.

Nas, C 'Turkish Identity and The Perception of Europe' in Marmara Journal of European Studies 9(1): 177-190.

'One for its Partner, One for the EU' in Radikal 6 March 2002, p. 1.

'Avrupa Terorde Hatali' ('Europe is Wrong on Terrorism') in Radikal 29 May 2002, p. 8.

Radikal 8 June 2002.

Sarup, M (1996) Identity, Culture and the Post-Modern World Edinburgh: Edinburgh University Press.

Sever, M (2002) 'Solda Yeni Arayislar' ('New Seekings on the Left)' in Radikal 20 May, p. 4.

Smith, A. D (1995) Nations and Nationalism in a Global Era Cambridge: Polity Press.

Taskin, Y (2001) '12 Eylul Ataturkculugu ya da Bir Kemalist Restorasyon Tessebusu Olarak 12 Eylul' ('The Kemalism of 12 September, or 12 September as an Attempt of Kemalist Restoration') in A. Insel (ed.) Modern Turkiye'de Siyasi Dusunce: Kemalism (Political Thought in Modern Turkey) Iletisim.

Tekeli, I. and S. Ilkin (1993) Turkiye ve Avrupa Birligi: Ulus Devletini Asma Cabasindaki Avrupaya Turkiye'nin Yaklasimi Ankara: Umit Yayincilik. 
Ugur, M (1999) The European Union and Turkey: An Anchor/Credibility Dilemma Aldershot: Ashgate.

Yavuz, H (2001) 'Degisen Turk Kimligi ve Dis Politika: Neo-Osmanliciligin Yukselisi' ('Turkish Identity and Foreign Policy in Flux: The Rise of Neo-Ottomanism') in S. Calis et al. (eds.) Turkiye'nin Dis Politika Gundemi: Kimlik, Demokrasi ve Guvenlik (The International Political Agenda of Turkey: The Identity, Democracy and Security) Ankara: Liberte. 